\title{
DENR Gene
}

National Cancer Institute

\section{Source}

National Cancer Institute. DENR Gene. NCI Thesaurus. Code C92524.

This gene plays a role in translation. 